\title{
DISASTER INSURANCE IN DEVELOPING ASIA: AN ANALYSIS OF MARKET-BASED SCHEMES
}

Swenja Surminski, Architesh Panda, and Peter John Lambert

NO. 590

September 2019
ADB ECONOMICS WORKING PAPER SERIES 


\section{Disaster Insurance in Developing Asia: An Analysis of Market-Based Schemes}

Swenja Surminski, Architesh Panda, and Peter John Lambert

No. 590 | September 2019
Swenja Surminski (s.surminski@lse.ac.uk) is Head of Adaptation Research and Architesh Panda

(a.panda1@Ise.ac.uk) is Research Officer at the Grantham Research Institute on Climate Change and the

Environment, London School of Economics and Political Science. Peter John Lambert (p.j.lambert@lse.ac.uk) is a PhD candidate in economics from the London School of Economics and Political Science.

This paper was prepared as background material for the Asian Development Outlook 2019 theme chapter on "Strengthening Disaster Resilience."

The authors wish to acknowledge research funding from the IGA-Rockefeller Resilience Research, the Grantham Foundation for the Protection of the Environment, and the United Kingdom's Economic and Social Research Council. 
(C) 2019 Asian Development Bank 6 ADB Avenue, Mandaluyong City, 1550 Metro Manila, Philippines

Tel +632632 4444; Fax +6326362444

www.adb.org

Some rights reserved. Published in 2019.

ISSN 2313-6537 (print), 2313-6545 (electronic)

Publication Stock No. WPS190149-2

DOI: http://dx.doi.org/10.22617/WPS190149-2

The views expressed in this publication are those of the authors and do not necessarily reflect the views and policies of the Asian Development Bank (ADB) or its Board of Governors or the governments they represent.

ADB does not guarantee the accuracy of the data included in this publication and accepts no responsibility for any consequence of their use. The mention of specific companies or products of manufacturers does not imply that they are endorsed or recommended by ADB in preference to others of a similar nature that are not mentioned.

By making any designation of or reference to a particular territory or geographic area, or by using the term "country" in this document, $A D B$ does not intend to make any judgments as to the legal or other status of any territory or area.

This work is available under the Creative Commons Attribution 3.0 IGO license (CC BY 3.0 IGO)

https://creativecommons.org/licenses/by/3.o/igo/. By using the content of this publication, you agree to be bound by the terms of this license. For attribution, translations, adaptations, and permissions, please read the provisions and terms of use at https://www.adb.org/terms-use\#openaccess.

This CC license does not apply to non-ADB copyright materials in this publication. If the material is attributed to another source, please contact the copyright owner or publisher of that source for permission to reproduce it. $\mathrm{ADB}$ cannot be held liable for any claims that arise as a result of your use of the material.

Please contact pubsmarketing@adb.org if you have questions or comments with respect to content, or if you wish to obtain copyright permission for your intended use that does not fall within these terms, or for permission to use the ADB logo.

Corrigenda to ADB publications may be found at http://www.adb.org/publications/corrigenda.

Note:

In this publication, “\$” refers to United States dollars.

The ADB Economics Working Paper Series presents data, information, and/or findings from ongoing research and studies to encourage exchange of ideas and to elicit comment and feedback about development issues in Asia and the Pacific. Since papers in this series are intended for quick and easy dissemination, the content may or may not be fully edited and may later be modified for final publication. 


\section{CONTENTS}

TABLES AND FIGURE

ABSTRACT V v

$\begin{array}{ll}\text { I. INTRODUCTION } & 1\end{array}$

II. CONTEXT:RESILIENCE AND INSURANCE 2

III. $\quad$ METHODS AND DATA 6

A. $\quad$ About the Data 6

B. $\quad$ Transfer of Risk 6

C. $\quad$ Ex ante Market-Based Risk Transfer Instruments 6

D. Scheme Types and Sectors $\quad 7$

E. Limitations of the Database 8

IV. CURRENT LANDSCAPE OF INSURANCE FOR DISASTER AND CLIMATE RISKS 8 IN ASIA

A. Overview 8

B. Comparing Past and Present Landscape of Risk Transfer Schemes in Asia 8

C. Risk Transfer Schemes Operating across Asia 10

D. Delivery of Disaster Risk Transfer Schemes 12

E. Incentives for Disaster Risk Transfer Schemes 13

$\begin{array}{ll}\text { F. Agricultural Insurance } & 15\end{array}$

$\begin{array}{lll}\text { V. } & 19\end{array}$

VI. DISCUSSION AND CONCLUSION 23

DATA APPENDIX $\quad 25$

A. Introduction 25

B. What Constitutes a "Scheme"? $\quad 25$

C. Purpose and History of the Database 26

D. Sample Bias and Limitations 26

$\begin{array}{ll}\text { REFERENCES } & 27\end{array}$ 


\section{TABLES AND FIGURE}

\section{TABLES}

$1 \quad$ Most Common Barriers for Climate and Disaster Insurance in Emerging Markets 5 and Developing Countries

2 Top Level Categorization of Different Insurance Scheme Types and Sectors 7

3 Comparison of Number of Active Risk Transfer Schemes by Region, 2012-2018 9

$4 \quad$ Comparison of Number of Active Risk Transfer Schemes by Economy, 2012-2018 9

$5 \quad$ Number of Disaster Insurance Schemes in Asia by Region and Type, 2018

$6 \quad$ Number of Disaster Insurance Schemes in Asia by Economy and Type 11

$7 \quad$ Number of Single-Peril or Multiperil Schemes 12

$8 \quad$ Number of Schemes that Covers Agricultural Losses Explicitly 12

$9 \quad$ Final Delivery Channel by Type 13

10 Number of Schemes with Financial Support 13

11 Schemes with Financial Support by Scheme Type 14

12 Count of Schemes where Insurance was Compulsory or Bundled 15

13 Count of Agricultural Insurance Schemes in the Database 16

14 Count of Agricultural Insurance Scheme by Payout Mechanisms 16

15 Overview of Agricultural Insurance Markets across Asia 18

16 Resilience and Disaster Risk Transfer Schemes 21

17 Evidence from Munich Climate Insurance Initiative's InsuResilience Review 22

on Climate Insurance for the Poor

\section{FIGURE}

Fiscal Disaster Risk Assessment and Risk Financing Options 


\begin{abstract}
In recent years, insurance against natural disasters has gained recognition as an important tool for climate risk management that could, if carefully implemented, help increase the resilience of those insured. In response, insurance solutions are increasingly tested and applied in many countries that have no prior experience with insurance or no existing market. This paper analyzes the status, types, and patterns of market-based disaster insurance schemes across emerging and developing countries in Asia. We provide a snapshot of the current use of insurance based on data from Grantham Research Institute on Climate Change and the Environment's Disaster Risk Transfer Scheme Database (20122018). Our analysis shows that although the use of insurance is expanding, there are many countries that still don't have any kind of cover available. Where insurance mechanisms exist, they often rely on subsidies or bundling strategies. Although a mix of insurance schemes covering risks for governments (sovereign); or at meso (risk aggregators, cooperatives); and micro level currently operate to address a wide variety of climate and disaster risks, without demand-side support, many markets are likely to collapse or, at the very least, experience far lower penetration rates. We conclude with a discussion of the role of these insurance schemes in increasing resilience, which raises important questions for designing new and measuring and evaluating existing insurance schemes.
\end{abstract}

Keywords: Asia, climate change, disaster insurance, resilience

JEL codes: G22, G32, Q54 


\section{INTRODUCTION}

Climate change threatens the sustainable development of society, with particularly negative implications for poor and vulnerable communities. Risk reduction and forward-looking climate adaptation are important in building resilience of individuals, businesses, and governments to the impacts of extreme weather and long-term changes. The economic case for proactive management of these risks and for avoidance of further risk creation is strong (Surminski and Tanner 2016). The increasing costs associated with the physical impacts of climate change hamper development efforts in many parts of the world. Low-income countries are at the greatest risk of climate hazards, mainly because of their reliance on climate-sensitive natural resources and agriculture, as well as a lack of adaptive capacity (Intergovernmental Panel on Climate Change 2014). Building climate resilience therefore needs to be an essential component of current and future development planning to ensure that previous gains in poverty reduction and economic prosperity are not wiped out by adverse climatic impacts.

Among the many resilience measures, financial risk transfer as an intervention tool is experiencing growing interest from governments, donors, businesses, and civil society (Surminski Bouwer, and Linnerooth-Bayer 2016; Weingärtner, Simonet, and Caravani 2017). Insurance is considered a possible way to reduce or compensate for economic losses from disasters through ex ante risk management, with agriculture insurance already used in several countries as a safety net to protect farmers and combat food security concerns (Golnarghi, Surminski, and Schanz 2016; Tanner et al. 2015). In this spirit, the InsuResilience Global Partnership for Climate and Disaster Risk Finance and Insurance Solutions was officially launched at the United Nations Climate Conference of the Parties 23 (COP23) in Bonn. At the global level, different multilateral initiatives such as the Sendai Framework for Disaster Risk Reduction include risk transfer and insurance mechanisms (paragraph 30a and 31b, A/conf.224/CR.P.3), while insurance-related approaches are also featured in the Paris Agreement (United Nations Framework Convention on Climate Change COP21, 1/CP.21: Article 3, para. 48; Paris Agreement: Article 8, para. 4). Indeed, insurance instruments can play an important role in managing risks by providing "individuals and businesses with coverage against specified contingencies, by redistributing losses among the pool of policyholders" (Hussels, Ward, and Zurbruegg 2005). This pooling of risks allows for diversification, providing an additional layer of risk absorption capacity. However, beyond the financial dimension, insurance can also affect the behavior of those at risk, either in a moral hazard context, where insurance can induce risky behavior, or as an incentive, where insurance triggers risk reduction investments or the implementation of prevention measures (Surminski 2014).

In low-income countries, typically more than $95 \%$ of all losses from weather, climate, and natural hazards remain uninsured (Golnarghi, Surminski, and Schanz 2016). For example, in Asia, Bangladesh is the country with the least insurance penetration at $0.2 \%$ of gross domestic product (GDP); in comparison to Japan, where insurance penetration is $2.3 \%$ of GDP (Lloyds of London 2018). Where insurance does exist, the insurance market is predominantly concentrated in the agriculture sector. For example, in recent years, both indemnity and index-based agricultural insurance has strongly developed in Asia, from traditional market leaders of India to the People's Republic of China (PRC), to new schemes in Indonesia, the Philippines, Thailand, and Viet Nam.

As climate change progresses, reducing and managing financial impacts from climate-related disasters and extreme events is becoming increasingly important in developing countries. If insurance is to play a role in supporting this quest for resilience, more needs to be done to design and implement 
schemes that address current and future risk and increase not only financial resilience but help to reduce risk and avoid further risk creation. This raises many questions about design, scope, and viability of risk transfer schemes, their benefits and costs, and if and how insurance can be supported though government intervention, donor money, or international adaptation assistance (Surminski and Vivid Economics 2018). This also underpins the need for creating necessary preconditions for the use of insurance through public policy and regulation, shaping the operating environment of the industry, and establishing if and how these schemes do meet the needs of those that they seek to cover (Ranger and Surminski 2013).

Although the potential benefits of insurance in the context of climate risks has been recognized for some time now, for example in the context of crop insurance (Di Falco et al. 2014 Panda et al. 2013), there are also clear concerns about possible disincentives or maladaption through insurance (e.g., O'Hare, White, and Connelly 2016). While in theory, well-designed and implemented insurance could help realize the "triple dividend of resilience" in terms of reducing loss and damage in the event of a disaster, managing risk of potential future disasters, and generating development cobenefits (Surminski and Tanner 2016), in reality, this resilience impact remains far from clear.

This paper analyzes the status, types, and patterns of market-based disaster insurance schemes across emerging and developing countries in Asia, and discusses their role in increasing resilience, which raises important questions for measuring and evaluating insurance schemes. We provide a snapshot of the current use of insurance to enhance the knowledge base for donors, insurers, governments, and broader practitioners operating in disaster risk management and insurance in low and lower-middle-income economies. Our analysis is based on an empirical assessment of schemes in Asia-based on data from the Grantham Research Institute on Climate Change and the Environment's Disaster Risk Transfer Scheme Database (2012-2018) (formerly known as the Climate Wise Compendium on Disaster Risk Transfer Schemes in emerging and developing countries).

\section{CONTEXT: RESILIENCE AND INSURANCE}

The concept of resilience has received significant attention recently, becoming a widely recognized part of the sustainable development and climate adaptation movement. There has been substantial discussion on the meaning, nature, and implications of resilience in the literature (Schipper and Langston 2015; Bahadur, Ibrahim, and Tanner 2010; Béné et al. 2012). However, defining and measuring resilience has not been straightforward and involves varied approaches and methodologies in different context. In the most basic sense, resilience can be understood as the ability of a system and its component parts to anticipate, absorb, accommodate, or recover from the effects of a hazardous event in a timely and efficient manner, including through ensuring the preservation, restoration, or improvement of its essential basic structures and functions (Intergovernmental Panel on Climate Change 2012). Risk transfer is understood to be one tool in a holistic climate risk management framework that can increase resilience to climate risks, as highlighted by the InsuResilience initiative launched in 2015 by the Group of Seven leaders, with a unique mandate to extend climate insurance to 400 million highly exposed, uninsured poor and vulnerable people by 2020 to make those individuals, communities, and countries more climate resilient (InsuResilience 2017). ${ }^{1}$

\footnotetext{
The Group of Seven consists of Canada, France, Germany, Italy, Japan, the United Kingdom, and the United States.
} 
However, while the positive relationship between other types of insurance (e.g., health or life insurance) and economic growth has been explored in detail (see Ghosh 2013, Alhassan and Fiador 2014, Dash et al. 2018), the empirical evidence on the benefits of market-based disaster and climate risk insurance, and in particular their impact on resilience, is still scarce. Recent research on the insurance penetration rate and resilience at the global level finds that the effect of natural disasters depends on access to insurance via private insurance markets and suggests that private insurance penetration and a stable public institutional infrastructure help build resilience to the negative effects of natural disasters (Breckner et al. 2016). However, importantly, insurance is not suitable for all risks nor for all stakeholders, and it does not provide a silver bullet to the challenge of climate risks. As such, it is important to consider aims and objectives behind any type of insurance, types of designs and operations, as well as the needs of those targeted by insurance (Linnerooth-Bayer et al. 2019). This is critical, as the extension of climate insurance to these populations may itself be risky. Poorly designed and/or implemented climate insurance may reduce incentives for risk reduction (Surminski and Oramas-Dorta 2014) increasing moral hazard and potentially lowering resilience. Ensuring that climate insurance is enhancing resilience and well-being requires both appropriate resilience indicators and well-designed studies that can be evaluated with rigor. A recent review, conducted by project partner, the Munich Climate Insurance Initiative, highlighted significant uncertainty around which resilience indicators to use in the monitoring and evaluation of insurance initiatives, and also a shortage of rigorously designed studies to examine how climate insurance influences resilience and measures of well-being such as food security and transitions from poverty (Schaefer and Waters 2016, Hess and Hazell 2016). Questions of type, form, and structure of such markets with respect to their viability in developing countries are now of key importance. More important, any insurance comes at a cost. The ratio of the premium paid versus the coverage obtained is an important consideration, particularly when comparing insurance to other risk financing tools. Ghesquiere and Mahul (2010) investigated this for a range of disaster risk financing instruments, looking at the ratio between the (opportunity) cost of the financial product (e.g., premium of an insurance product, expected net present value of a contingent debt facility) and the expected payout of that financial product. They found that disaster risk transfer is very costly compared to most other instruments, but offers the important advantages of more financing, speed, and certainty of disbursement (Ghesquiere and Mahul 2010, Clarke et al. 2016).

Overall, insurance theory and recent cost-benefit assessments indicate that risk financing is only viable for large and residual risks that cannot be reduced or managed otherwise (Mechler et al. 2014). This suggests that a "risk-layering approach" can be used to identify risk management options that are differentially effective for low-, medium- and high-probability events, as well as tailored to the different risk-bearing capacities of communities, governments, and international organizations. A similar approach has been used by World Bank (2016a) to identify fiscal risk assessment and risk financing options (see figure). 


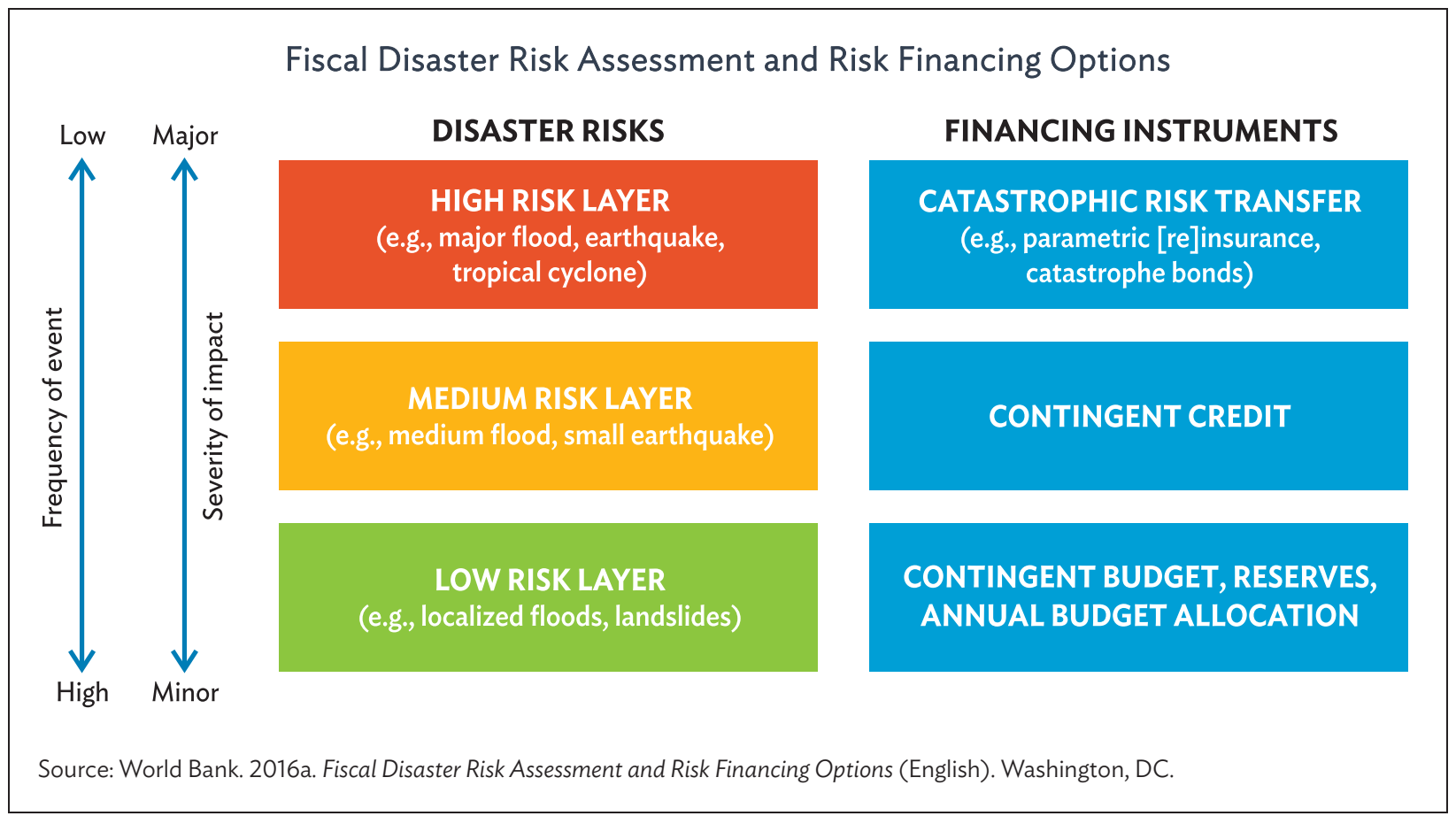

Furthermore, most developing countries face many barriers for implementing climate and disaster insurance as summarized in Table 1. The barriers to implementation of disaster insurance might arise because of demand-side or supply-side constraints. Common demand-side constraints include unaffordability, lack of trust, lack of financial literacy, lack of willingness to pay, and unsupportive regulatory frameworks. The level of insurance demand can be influenced by many factors including legal, social, economic, and political factors (Beck and Webb 2003, Esho et al. 2004). The supply-side constraints include unsuitable insurance risks such as slow onset disasters, lack of data, weak institutional frameworks, problems of asymmetric information (e.g., moral hazard or adverse selection) and lack of technical capacity. 


\section{Table 1: Most Common Barriers for Climate and Disaster Insurance in Emerging Markets and Developing Countries}

\begin{tabular}{|c|c|}
\hline Demand Side & Supply Side \\
\hline $\begin{array}{l}\text { Low income and/or unaffordability } \\
\text { Insurance is often considered too expensive for those } \\
\text { most vulnerable. }\end{array}$ & $\begin{array}{l}\text { Risk characteristics } \\
\text { The type of risks and risk trends determine the appetite of } \\
\text { those underwriting and the costs of an insurance scheme. } \\
\text { For some risks, such as slow-onset sea level rise, insurance } \\
\text { is deemed not suitable and not available. }\end{array}$ \\
\hline $\begin{array}{l}\text { Lack of trust } \\
\text { in the insurance mechanism or those running it, often due } \\
\text { to lack of experience with insurance. }\end{array}$ & $\begin{array}{l}\text { Lack of data to accurately price risks } \\
\text { often due to missing data collections, outdated risk } \\
\text { information, or lack of standardization or access to risk } \\
\text { data }\end{array}$ \\
\hline $\begin{array}{l}\text { Lack of financial literacy } \\
\text { can lead to misunderstanding of risks and the role of } \\
\text { insurance, and wrong expectations about payouts. }\end{array}$ & $\begin{array}{l}\text { "Classic" asymmetric information problems } \\
\text { Moral hazard and adverse selection problems imply that } \\
\text { those that are willing to pay for insurance are usually those } \\
\text { most at risk and hence costly to insure. }\end{array}$ \\
\hline $\begin{array}{l}\text { Existence of alternative measures } \\
\text { including humanitarian assistance, social safety networks, } \\
\text { which may reduce the interest in insurance. }\end{array}$ & $\begin{array}{l}\text { Lack of technical capacity } \\
\text { Risk financing and insurance require technical skills that } \\
\text { are often not present in emerging markets or developing } \\
\text { countries. }\end{array}$ \\
\hline $\begin{array}{l}\text { Limited willingness to pay } \\
\text { Particularly for sovereign risk schemes, the lack of political } \\
\text { buy-in and political attractiveness of postdisaster aid } \\
\text { present challenges. }\end{array}$ & $\begin{array}{l}\text { High operational or distribution costs } \\
\text { Administrative aspects and lack of distributional networks } \\
\text { can put a burden on insurance schemes, particularly in } \\
\text { their early phases. }\end{array}$ \\
\hline $\begin{array}{l}\text { Unsupportive regulatory frameworks } \\
\text { Lack of enforcement of customer rights and lack of } \\
\text { transparency with regard to insurance policies may create } \\
\text { deterrents for (potential) customers to make use of } \\
\text { insurance services. }\end{array}$ & $\begin{array}{l}\text { Unsupportive regulatory frameworks } \\
\text { This may act as a deterrent for private sector involvement } \\
\text { and can hamper the scaling up of insurance schemes. }\end{array}$ \\
\hline
\end{tabular}

Sources: Authors, based on Ranger, Nicholas, and Swenja Surminski. 2013. "A Preliminary Assessment of the Impact of Climate Change on Non-life Insurance Demand in the BRICS Economies." International Journal of Disaster Risk Reduction 3: 14-30. https://doi.org/10.1016/j.ijdrr.2012.11.004; Vivid Economics, Surminski Consulting, and Callund Consulting. 2016. "FINAL REPORT: Understanding the Role of Publicly Funded Premium Subsidies in Disaster Risk Insurance in Developing Countries." United Kingdom Department for International Development.

The following section offers a snapshot of existing disaster and climate risk transfer schemes across Asia. While this data offers little in the way of specific resilience outcomes, it helps one get an overview of the current landscape, as well as answers important questions such as the role of government, the role of demand-side support, and different types of supply-side instruments and how, if at all, these are linked to initiatives to improve resilience. 


\section{METHODS AND DATA}

\section{A. About the Data}

This paper utilizes data from the Grantham Research Institute on Climate Change and the Environment's Disaster Risk Transfer Scheme Database (2012-2018, henceforth "database") to describe the landscape of insurance for natural disasters and perils throughout Asia. This data has been developed over many years, with the original version compiled for ClimateWise (2012), and an update for the United Kingdom's Department for International Development in 2016 (Vivid Economics, Surminski Consulting, and Callund Consulting 2016). In this paper, market-based insurance has been defined to distinguish insurance markets from social-safety-net-type measures such as social insurance, which includes, for example, social protection from unemployment and disability. Each scheme in the database is defined by two key properties: (i) the transfer of risk away from entities in low- or middle-income countries, and (ii) the use of one or more ex ante market-based risk transfer instruments.

\section{B. Transfer of Risk}

The first dimension of our definition of a scheme pertains to the transfer of risk. The type of risks we focus on are those related to weather, climate, and other natural hazards. These include: droughts, floods, hail, storms, frost, disease, fire, landslides, tsunamis, earthquakes, typhoons, and pest infestations. To limit the scope of research and maintain focus on natural disasters, we do not include insurance for secondary harms that might follow, such as life insurance, health insurance, and income protection, etc.

The entities that each scheme is concerned with (beneficiaries; those who are covered through a scheme) vary, but are largely captured by three groups:

- Groups of individuals / households / smallholder farmers

- Public and private organizations (e.g., businesses, microfinance institutes, nongovernment organizations, public authorities)

- Governments (national, provincial, or local)

Many governments are buying some form of insurance for their own properties, for example public assets against fire; in some cases, this also includes a degree of protection against natural disasters and climate risks. The database is unlikely to capture these, unless the cover is part of a dedicated sovereign risk scheme. Information about any public assets insured is often very difficult to obtain unless a full country case study is conducted-for example as part of the scoping work of the Asian Development Bank (ADB) for city-level insurance schemes in the Philippines and Viet Nam (ADB 2015, 2018). Even within countries, there tends to be no clear overview of which government assets may be protected and to what standard. This is a clear limitation and an area that will require further work to improve understanding of risk transfer and exposure and to avoid possible duplication of coverage.

\section{Ex ante Market-Based Risk Transfer Instruments}

The second dimension of our definition of a "scheme" (or a single entry in the database) pertains to the use of an ex ante market-based risk transfer instrument. Ex ante refers to the fact that risk is transferred before a hazardous event occurs. "Market-based insurance" in this paper implies a market 
for disaster and climate risk insurance, where insurance can be purchased by those seeking protection. This does not necessarily have to be a purely private market-indeed most schemes captured in the database show government involvement-and it also does not imply a voluntary purchasing decision or a market-based pricing approach. ${ }^{2}$ For more discussion of how the collection of schemes in the database was compiled (see Data Appendix).

\section{Scheme Types and Sectors}

While the full list of definitions and data can be seen from the Grantham Research Institute's database, Table 2 gives an overview of some top-level categorizations used in the data.

\section{Table 2: Top Level Categorization of Different Insurance Scheme Types and Sectors}

\begin{tabular}{|c|c|}
\hline \multicolumn{2}{|l|}{ Scheme Type } \\
\hline Sovereign risk transfer & $\begin{array}{l}\text { Schemes that aim to increase the financial response capacity of governments in } \\
\text { the aftermath of natural disasters, while protecting their long-term fiscal balances } \\
\text { through the use of risk transfer instruments, including insurance }\end{array}$ \\
\hline $\begin{array}{l}\text { SME and/or private property risk } \\
\text { transfer }\end{array}$ & $\begin{array}{l}\text { Schemes aimed at increasing property catastrophe insurance penetration among } \\
\text { homeowners, small and medium-sized enterprises, and public entities }\end{array}$ \\
\hline Meso-level risk transfer & $\begin{array}{l}\text { Schemes that provide cover for "risk aggregators" such as banks, microfinance } \\
\text { institutions, agribusinesses, or municipal-level actors (e.g., water authorities) }\end{array}$ \\
\hline Microinsurance & $\begin{array}{l}\text { Schemes that facilitate access to disaster insurance products for individuals, often } \\
\text { aimed to protect the livelihoods of the poor against extreme events }\end{array}$ \\
\hline \multicolumn{2}{|l|}{ Scheme Sector } \\
\hline Agricultural & $\begin{array}{l}\text { Schemes aimed at farmers, herders, and agricultural financing institutions (e.g., } \\
\text { rural banks, microfinance institutions) to increase their financial resilience to } \\
\text { adverse natural hazards through insurance }\end{array}$ \\
\hline Nonagricultural & Insurance not directly linked to agriculture \\
\hline \multicolumn{2}{|c|}{$\begin{array}{l}\text { SME = small and medium-sized enterprise. } \\
\text { Note: Refer to the definitions in section III.B for further information on micro, SME, meso, and sovereign schemes. } \\
\text { Source: Authors' own based on data from Grantham Research Institute on Climate Change and the Environment. 2012-2018. Disaster Risk } \\
\text { Transfer Scheme Database. http://www.Ise.ac.uk/GranthamInstitute/evaluating-the-resilience-impact-of-climate-insurance-erici/ (accessed } \\
\text { April 2019). }\end{array}$} \\
\hline
\end{tabular}

Schemes can also be subclassified as "index based" or "indemnity based," according to the type of insurance instrument used. Index-based insurance involves parametric insurance that covers the probability of a predefined event happening instead of indemnifying actual loss incurred. In the case of indemnity-based insurance, the payout is triggered by actual loss or damage to a physical asset such as crops. For example, consider a specific crop exposed to a risk, for example, drought. Suppose a farmer owns this crop and takes out crop insurance against drought. Indemnity covers the damage

2 We restrict our attention to "market-based" schemes to ensure consistency and comparability. Many "nonmarket" approaches to risk transfer also exist, such as informal lending networks, precautionary savings, semiliquid buffer capital stocks. These are notoriously difficult to gather data on and are not considered in our analysis. 
incurred by the insured party as established by a loss adjuster as soon as the damage occurs. On the other hand, in the case of index insurance, policy holders get a payout based on a predetermined indicator (e.g., the amount of rainfall) which triggers a payment to all insured clients once the indicator crosses the predetermined threshold.

\section{E. Limitations of the Database}

The database pools information on as many disaster insurance schemes in developing and emerging countries across Asia as possible. It offers a comprehensive but not complete picture, due to some data limitations relating to available information in English versus other languages and a lack of data about the scale of the scheme. There are also higher chances that the collected information for the database is biased toward available sources from public schemes, since for purely private schemes information may not be available publicly (see Data Appendix D for details).

\section{CURRENT LANDSCAPE OF INSURANCE FOR DISASTER AND CLIMATE RISKS IN ASIA}

\section{A. Overview}

Asia and the Pacific region comprise 45 developing economies and three developed economies (ADB 2018). Since the 1980s, these economies across Asia have become hotspots of economic growth and lead the charge in reducing global poverty. However, these economies face high exposure to disaster and climate risks, making them vulnerable to the ongoing impact of global climate change. Recently, the United Nations Economic and Social Commission for Asia and the Pacific (2018) stressed that only about $8 \%$ of catastrophe losses in Asia and the Pacific are insured, despite the region having suffered almost $\$ 1.3$ trillion in losses over the last 50 years. In the latest revision of the database, we identified a total of 53 schemes that aimed at providing disaster or climate risk insurance to developing economies in Asia.

\section{B. Comparing Past and Present Landscape of Risk Transfer Schemes in Asia}

Comparing the 2018 database to the data collected in 2012, we observe an overall increase in schemes operating across Asia.

In 2012, there were 35 schemes actively transferring risk, compared to 53 operating today. Table 3 breaks this down by region, showing the expansion in the number of schemes, which also appears to correlate with increasing levels of penetration and coverage (Microinsurance Network 2018). ${ }^{3}$

Looking across economies, we see from Table 4 that the majority of new schemes come from expansion at the extensive margin (where economies with zero schemes in 2012 now have one or two schemes in operation). The biggest expansions along the intensive margin have occurred in the PRC, the Philippines, and Bangladesh. None of the economies have seen a reduction in the number of risk transfer schemes in operation.

3 Recall that "schemes" do not accurately reflect coverage or penetration, since they include both very small and very large entries. In this case, we anecdotally observe that coverage has also increased substantially between 2012 and 2018 , but our data does not allow for this comparison. 


\section{Table 3: Comparison of Number of Active Risk Transfer Schemes by Region, 2012-2018}

\begin{tabular}{lcc}
\hline Asian Region & 2012 & 2018 \\
\hline Central & 0 & 1 \\
East & 7 & 8 \\
Pacific & 0 & 2 \\
South & 20 & 24 \\
Southeast & 8 & 18 \\
\hline
\end{tabular}

Note: See Table 6 for the breakdown of each country by region.

Source: Authors' own based on data from Grantham Research Institute on Climate Change and the Environment. 2012-2018. Disaster Risk Transfer Scheme Database. http://www.Ise.ac.uk/GranthamInstitute/evaluating-the-resilience-impact-ofclimate-insurance-erici/ (accessed April 2019).

\section{Table 4: Comparison of Number of Active Risk Transfer Schemes by Economy, 2012-2018}

\begin{tabular}{lcc}
\hline Economy & 2012 & 2018 \\
\hline Bangladesh & 2 & 5 \\
Cambodia, Lao People's Democratic Republic, and Myanmar & 1 \\
Cambodia and Myanmar & 0 & 1 \\
China, People's Republic of & 0 & 6 \\
Cook Islands, Marshall Islands, Samoa, Tonga, and Vanuatu & 5 & 1 \\
Fiji & 0 & 1 \\
India & 15 \\
Indonesia & 0 & 4 \\
Kazakhstan & 14 & 1 \\
Mongolia & 2 & 1 \\
Myanmar & 0 & 2 \\
Nepal & 1 & 1 \\
Philippines & 0 & 1 \\
Sri Lanka & 2 & 7 \\
Taipei,China & 2 & 1 \\
Thailand & 2 & 1 \\
\hline Viet Nam & 3 & 1 \\
\hline
\end{tabular}

Note: Economies are in alphabetical order and are grouped according to their participation in the same scheme. Some economies appear twice because they might belong to two or more different schemes, for example, Myanmar.

Source: Authors' own based on data from Grantham Research Institute on Climate Change and the Environment. 2012-2018. Disaster Risk Transfer Scheme Database. http://www.lse.ac.uk/Granthamlnstitute/evaluating-theresilience-impact-of-climate-insurance-erici/ (accessed April 2019). 
In the next section, we leave behind the 2012 data and focus on deconstructing the information from the 2018 database, exploring different aspects of the landscape of risk transfer schemes across low- and middle-income countries in Asia.

\section{Risk Transfer Schemes Operating across Asia}

Looking at all the disaster risk transfer schemes from the database provides a snapshot of how the region is currently using insurance for addressing natural hazards. This section further unpacks different features of the schemes in operation and offers insights about the types of ex ante marketbased risk transfer instruments operating to transfer these risks.

Table 5 describes the current landscape of insurance schemes operating (or soon to be operational) across developing Asian economies. We see that the majority of schemes (71\%) deliver microinsurance. The prevalence of these schemes is unsurprising, since they are small (as few as 400 policies, as in a pilot program for rice paddy farmers in Myanmar), and are also easily linked to existing microfinance schemes. Microinsurance schemes across Asia typically operate at the local or state level or apply to a small subgroup (e.g., PepsiCo's index weather insurance scheme for potato farmers in India). We also see that $14 \%$ of all schemes in operation are larger sovereign risk schemes. These schemes range from single country (e.g., earthquake insurance bonds held by the government of the PRC) to regional (e.g., the Pacific Catastrophe Risk Assessment and Financing Initiative, which pools together sovereign disaster risks across 15 Pacific nations). A small number (5\%) of schemes operate to cover risks to private property held by small and medium-sized enterprises. Finally, $10 \%$ of schemes insure institutions at the meso level (e.g., VisionFund's scheme insures microfinance institutes across Cambodia and Myanmar).

Table 5: Number of Disaster Insurance Schemes in Asia by Region and Type, 2018

\begin{tabular}{lcccc}
\hline Asian Region & Micro & SME & Meso & Sovereign \\
\hline Central & 1 & - & - & - \\
East & 5 & 2 & 2 & 2 \\
Pacific & 1 & - & - & 1 \\
South & 22 & - & 1 & 2 \\
Southeast & 13 & 1 & 3 & 3 \\
Total & 42 & 3 & 6 & 8 \\
\hline$\%$ & 71 & 5 & 10 & 14 \\
\hline
\end{tabular}

meso = scheme that provides cover for "risk aggregators" such as banks, microfinance institutions, agribusinesses, or municipal-level actors (e.g., water authorities); micro = microenterprise; SME = small and medium-sized enterprise.

Notes: Six schemes span two insurance types and were thus "double counted" (e.g., microinsurance and meso insurance for farmers and microfinance institutions). See Table 6 for the breakdown of each country by region.

Source: Authors' own based on data from Grantham Research Institute on Climate Change and the Environment. 2012-2018. Disaster Risk Transfer Scheme Database. http://www.lse.ac.uk/ GranthamInstitute/evaluating-the-resilience-impact-of-climate-insurance-erici/ (accessed April 2019).

Drilling down to the economy level, Table 6 further illuminates how the types of insurance schemes vary across specific economies. 
Table 6: Number of Disaster Insurance Schemes in Asia by Economy and Type

\begin{tabular}{|c|c|c|c|c|}
\hline Economy & Micro & SME & Meso & Sovereign \\
\hline Central: & 1 & - & - & - \\
\hline Kazakhstan & 1 & - & - & - \\
\hline East: & 5 & 2 & 2 & 2 \\
\hline China, People's Republic of & 4 & 2 & 1 & 1 \\
\hline Mongolia & 1 & - & 1 & - \\
\hline Taipei,China & - & - & - & 1 \\
\hline Pacific: & 1 & - & - & 1 \\
\hline $\begin{array}{l}\text { Cook Islands, Marshall Islands, Samoa, Tonga, and } \\
\text { Vanuatu }\end{array}$ & - & - & - & 1 \\
\hline Fiji & 1 & - & - & - \\
\hline South: & 22 & - & 1 & 2 \\
\hline Bangladesh & 5 & - & 1 & - \\
\hline India & 13 & - & - & 2 \\
\hline Nepal & 3 & - & - & - \\
\hline Sri Lanka & 1 & - & - & - \\
\hline Southeast: & 13 & 1 & 3 & 3 \\
\hline $\begin{array}{l}\text { Cambodia, Lao People's Democratic Republic, } \\
\text { and Myanmar }\end{array}$ & - & - & - & 1 \\
\hline Cambodia and Myanmar & - & - & 1 & - \\
\hline Indonesia & 2 & 1 & 1 & 1 \\
\hline Myanmar & 2 & - & - & - \\
\hline Philippines & 6 & - & 1 & 1 \\
\hline Thailand & 1 & - & - & - \\
\hline Viet Nam & 2 & - & - & - \\
\hline Grand Total & 42 & 3 & 6 & 8 \\
\hline
\end{tabular}

meso = scheme that provides cover for "risk aggregators" such as banks, microfinance institutions, agribusinesses, or municipal-level actors (e.g., water authorities); micro = microenterprise; SME = small and medium-sized enterprise.

Note: Table shows the number of schemes and illustrates regional spread. Economies are grouped according to region; some economies have been grouped together and some economies reappear at different groupings as they participate in different schemes at the same time.

Source: Authors' own based on data from Grantham Research Institute on Climate Change and the Environment. 2012-2018. Disaster Risk Transfer Scheme Database. http://www.Ise.ac.uk/Granthamlnstitute/evaluating-the-resilience-impact-of-climate-insurance-erici/ (accessed April 2019).

Table 6 shows that the database is weighted toward India, the Philippines, and the PRC as the top three countries in terms of number of disaster insurance schemes. These three countries represent the most mature markets (excluding developed countries) for disaster risk insurance across Asia. The PRC's agricultural insurance market is the second largest globally (Aon Benfield 2016) after the United States. In India, a long history of heavily subsidized agricultural insurance programs has led to high levels of uptake among smallholder farmers throughout most regions and across most crop types (e.g., The Modified National Agricultural Insurance Scheme). A key driver of uptake for the Philippines 
appears to be government mandate (such as compulsory multiperil crop insurance, $\mathrm{MPCl}$ ). Along with subsidies, making MPCI compulsory (or bundling it with financial services) has helped develop the market over a relatively short period.

Table 7 shows that the majority of insurance contracts introduced as part of the schemes listed in the database have a slight bias toward multiperil coverage (60\%) compared to the $40 \%$ of schemes that promote single-peril insurance contracts.

Table 7: Number of Single-Peril or Multiperil Schemes

\begin{tabular}{lcl}
\hline & Count & $\%$ \\
\hline Multi & 31 & 60 \\
Single & 21 & 40 \\
\hline
\end{tabular}

Source: Authors' own based on data from Grantham Research Institute on Climate Change and the Environment. 2012-2018. Grantham Disaster Risk Transfer Scheme Database. http://www.Ise.ac.uk/GranthamInstitute/evaluating -the-resilience-impact-of-climate-insurance-erici/ (accessed April 2019).

We see from Table 8 that the losses covered by the majority of schemes in our database are agricultural losses (62\%). This is as expected, since our focus is on the risks from climate, weather, and other natural hazards, which are heavily linked to agricultural losses. Further, discussion of risk transfer schemes in the agriculture sector is given in section IV.F.

Table 8: Number of Schemes that Covers Agricultural Losses Explicitly

\begin{tabular}{lcc}
\hline & Count & $\%$ \\
\hline Agricultural & 32 & 62 \\
Nonagricultural & 18 & 35 \\
Both & 2 & 4 \\
\hline $\begin{array}{l}\text { Source: Authors' own based on data from Grantham Research Institute on Climate Change and the } \\
\text { Environment. 2012-2018. Grantham Disaster Risk Transfer Scheme Database. http://www.lse.ac.uk/ } \\
\text { Granthamlnstitute/evaluating-the-resilience-impact-of-climate-insurance-erici/ (accessed April 2019). }\end{array}$
\end{tabular}

\section{Delivery of Disaster Risk Transfer Schemes}

As has been discussed in section II, disaster risk transfer through the use of market-based instruments remains heavily underdeveloped, suggesting that certain roadblocks (e.g., low-income levels, weak institutional framework, and a lack of transparency or trust) still must be overcome. This section focuses on information available from the database that sheds light on how existing schemes have been able to deliver, support, and incentivize the uptake of risk transfer across low- and middleincome countries in Asia.

The ability to provide access to risk transfer instruments and ensure reach and delivery to those at risk is an important ingredient. Table 9 shows the breakdown of "final delivery channels," 
defined as beneficiary-facing entities. We see that more than half of schemes in the database offer risk transfer through private final delivery channels. These include insurance and credit retail outlets, as well as larger private or state-owned private entities.

Table 9: Final Delivery Channel by Type

\begin{tabular}{lc}
\hline & $\%$ \\
\hline International public entity & 11 \\
National public entity & 30 \\
NGO & 5 \\
Private (including SOE) & 54 \\
\hline & 100
\end{tabular}

$\mathrm{NGO}$ = nongovernment organization, $\mathrm{SOE}=$ state-owned enterprise.

Source: Authors' own based on data from Grantham Research Institute on Climate Change and the Environment. 2012-2018. Grantham Disaster Risk Transfer Scheme Database. http://www.lse.ac.uk/Granthamlnstitute/evaluating-the-resilience-impact-of-climateinsurance-erici/ (accessed April 2019).

\section{E. Incentives for Disaster Risk Transfer Schemes}

The database provides some information about strategies to increase uptake of market-based risk transfer instruments. Two approaches were widely used to incentivize uptake: (i) premium subsidies (to reduce or eliminate the out-of-pocket cost for beneficiaries) and (ii) compulsory acquisition and/or bundling (i.e., making the product compulsory for a group of individuals, or a compulsory add-on to other products like access to finance).

\section{(1) Premium Subsidies and Financial Support}

Table 10 shows that, of the schemes listed in the database, $57 \%$ had some kind of partial subsidy to bolster demand. A further $13 \%$ of schemes offered a full subsidy (making the product free of charge to those covered).

Table 10: Number of Schemes with Financial Support

\begin{tabular}{lcc}
\hline & Count & $\%$ \\
\hline None & 16 & 30 \\
Premium subsidy - partial & 30 & 57 \\
Premium subsidy - full & 7 & 13 \\
\hline Source: Authors' own based on data from Grantham Research Institute on Climate Change and the \\
Environment. 2012-2018. Grantham Disaster Risk Transfer Scheme Database. http://www.lse.ac.uk/ \\
Granthamlnstitute/evaluating-the-resilience-impact-of-climate-insurance-erici/ (accessed April 2019).
\end{tabular}

Table 11 shows how subsidies were used by the type of insurance provided. For example, it shows that only around one-third (31\%) of microinsurance schemes listed had no subsidy on offer. Importantly, climate risk insurance can be expensive and have high transactions costs, often making subsidies essential for uptake. 
Table 11: Schemes with Financial Support by Scheme Type

\begin{tabular}{lcccc}
\hline & Micro & SME & Meso & Sovereign \\
\hline None / no info & 13 & 1 & 2 & 2 \\
& $31 \%$ & $33 \%$ & $33 \%$ & $29 \%$ \\
\hline Premium subsidy - partial & 24 & 2 & 2 & 5 \\
\hline Premium subsidy - full & $57 \%$ & $67 \%$ & $33 \%$ & $71 \%$ \\
\hline
\end{tabular}

meso = scheme that provides cover for "risk aggregators" such as banks, microfinance institutions, agribusinesses, or municipal-level actors (e.g., water authorities); micro = microenterprise; $\mathrm{SME}=$ small and medium-sized enterprise.

Notes: Six schemes span two insurance types and were thus "double counted" (e.g., one scheme might be classified as "micro" and "meso") thus, horizontal summation may appear different to "total" in Table 10. Source: Authors' own based on data from Grantham Research Institute on Climate Change and the Environment. 2012-2018. Grantham Disaster Risk Transfer Scheme Database. http://www.lse.ac.uk/ Grantham Institute/evaluating-the-resilience-impact-of-climate-insurance-erici/ (accessed April 2019).

The choice of support measures for insurance can have implications for uptake, operations, and behavioral influence (Vivid Economics, Surminski Consulting, and Callund Consulting 2016). One example that has been investigated in greater detail is the Pacific Catastrophe Risk Insurance Pilot (PCRIP). Introduced in 2013, PCRIP was designed to increase the financial resilience of Pacific Island countries (PICs) against natural disasters by improving their capacity to meet postdisaster funding needs. Initial assessment indicated that countries in this region unanimously wished to purchase catastrophe insurance but would have been unable to afford it without premium subsidies because a full premium would impose significant strain on their national budgets (Narube 2015b). The Government of Japan's grant helped finance a majority of the PCRIP premium payments, but participants contributed approximately 5\% of the total premium cost in 2014 and 16\% in 2015 (Global Facility for Disaster Reduction and Recovery 2015). The World Bank (2015) suggests that these contributions from the PICs through the PCRIP reflect demand for sovereign insurance in the region. But Narube (2015b) observed that it seemed as though the decision to join the PCRIP was influenced heavily by the availability of insurance at no or little cost. This observation was validated by the PICs when it was indicated that they would "seriously evaluate their ongoing participation if premium ceases to be subsidised." In the same consultation report, Narube also mentions that countries believed the operational cost of maintaining the PCRIP would be significant and participants believed they would be unable to pay it from their national budgets. The quest for a more permanent premium support mechanism led to the creation of the Pacific Resilience Program using International Development Association grants and credits worth $\$ 32.29$ million (World Bank 2016c). The Pacific Resilience Program initiative allocated approximately $\$ 8$ million for investments in risk reduction and early warning initiatives, and the remaining to "disaster risk financing" activities, which include premium support (World Bank 2016b).

\section{(2) Compulsory Uptake and/or Bundling}

Moving to the mechanism of compulsory uptake and/or bundling of insurance, Table 12 shows that a third of schemes used this to increase demand for insurance. 
Table 12: Count of Schemes where Insurance was Compulsory or Bundled

\begin{tabular}{lcl}
\hline & Count & $\%$ \\
\hline Compulsory and/or credit linked & 18 & 34 \\
Noncompulsory & 35 & 66 \\
\hline
\end{tabular}

Source: Authors' own based on data from Grantham Research Institute on Climate Change and the Environment. 2012-2018. Disaster Risk Transfer Scheme Database. http://www.lse.ac.uk/Granthamlnstitute/evaluating-theresilience-impact-of-climate-insurance-erici/ (accessed April 2019).

Table 12 shows that the use of compulsory uptake and/or bundling is utilized across all insurance types, with roughly a third of schemes being compulsory. The major benefit of credit-linked insurance is the reduced possibility of default, which also improves the business case for providing credit to poorer, more vulnerable households. The literature also discusses other benefits and possible drawbacks, as well as challenges with credit linking, such as problems arising from basis risk for farmers for index insurance, liquidity problems for the farmers, and high cost to the insurer in administering the insurance (Meyer, Hazell, and Varangis 2017; Clarke and Dercon 2009; Farrin and Miranda 2015; Giné and Yang 2009).

In the Philippines, the three most prominent microinsurance schemes are all credit linked. The Philippine Crop Insurance Corporation offers a number of credit products with compulsory insurance, such as through the Area Based Yield Crop Insurance program covering 17 rice farming municipalities. This has allowed the government to leverage existing microcredit delivery infrastructure and allowed rapid expansion of microinsurance coverage.

\section{F. Agricultural Insurance}

Agriculture continues to be extremely important in many of the low- and middle-income countries in Asia and the Pacific region considered for this study. These countries range in size of GDP from $\$ 14$ trillion for the PRC (International Monetary Fund 1980-2018) to \$16.85 billion for the Lao People's Democratic Republic (Lao PDR) (World Bank 1960-2018). The share of agriculture in the GDP varies from 27\% of total GDP in Nepal to only 3\% of total GDP in the Lao PDR. According to the recent study by the Food and Agriculture Organization (FAO) (2016), developing countries' agriculture sectors absorb an average of $22 \%$ of the total damage and losses caused by natural hazards. Building disaster resilience of agriculture thus assumes significance beyond the economic impacts; it is also critical for improving livelihoods and reducing poverty in the region.

Looking specifically at developing countries, Table 13 identifies those schemes from the database directly involved in agriculture sector insurance. Results shows that South Asian, Southeast Asian, and Pacific countries have higher numbers of agricultural insurance schemes as compared to the East Asian economies. However, this does not provide insights into insurance coverage and penetration, which are very difficult to measure. 
Table 13: Count of Agricultural Insurance Schemes in the Database

\begin{tabular}{lcc}
\hline Asian Region & Count & $\%$ \\
\hline Central & 1 & 100 \\
East & 5 & 71 \\
Pacific & 0 & 0 \\
South & 15 & 63 \\
Southeast & 13 & 72 \\
\hline Grand Total & 31 & 58 \\
\hline
\end{tabular}

Source: Authors' own based on data from Grantham Research Institute on Climate Change and the Environment. 2012-2018. Disaster Risk Transfer Scheme Database. http://www.lse.ac.uk/ GranthamInstitute/evaluating-the-resilience-impact-of-climate-insurance-erici/ (accessed April 2019).

The spread and penetration of the agricultural insurance market in Asia is still small compared to developed countries, and mostly dominated by high government intervention and subsidy programs. For example, in 2005 only $13.4 \%$ of global agricultural insurance premiums were from emerging markets, which had increased to $22 \%$ in 2011, driven largely by major growth in Brazil, the PRC, and India (Swiss Re 2013). The agricultural insurance market in developing countries and specifically in Asia and the Pacific region have grown rapidly over the last decade. The global agricultural insurance premium volume jumped from $\$ 8$ billion in 2004 to $\$ 20$ billion in 2007, and of the 80\% of global premium volume covered by the survey, 91\% came from crop insurance (Mahul and Stutley 2010).

In the context of agricultural insurance, the most common (74\%) payout mechanism structure is index based (Table 14), with risk transfer based either on weather indices or other indices such as average area crop yield. This is a result of recent trends toward these parametric solutions, in response to well-known issues with indemnity insurance products (transaction costs, verifiability etc.) associated with developing country insurance markets. It is also the result of the advances in technology aiding the implementation of index-based insurance schemes (e.g., use of satellite data, advances in modeling methods, etc.).

Table 14: Count of Agricultural Insurance Scheme by Payout Mechanisms

\begin{tabular}{lcc}
\hline & Count & $\%$ \\
\hline Indemnity & 8 & 24 \\
Index & 25 & 74 \\
Both & 1 & 3 \\
\hline
\end{tabular}

Source: Authors' own based on data from Grantham Research Institute on Climate Change and the Environment. 2012-2018. Disaster Risk Transfer Scheme Database. http://www.lse.ac.uk/ Grantham Institute/evaluating-the-resilience-impact-of-climate-insurance-erici/ (accessed April 2019).

Asia has a long of history of introduction and growth of agricultural schemes. However, during the 1970s, many of the major public sector MPCI initiatives were introduced and piloted in Bangladesh, the PRC, India, the Philippines, and Thailand. However, these schemes did not achieve much coverage until the early years of the 21st century when the new schemes were introduced and revised, led by countries such as India and the PRC. Since then, there has been major expansion in public-private 
partnerships for crop and livestock insurance in Asia. There also have been introductions of new products, such as weather-index-based insurance schemes in a few countries. The first micro level or individual farmer weather-index-based insurance program was launched in India in Andhra Pradesh in 2003 by ICICl Lombard Insurance Company in conjunction with Bhartiya Samruddhi Investments and Consulting Services (BASIX), a local microfinance institution, for small and marginal farmers growing castor and groundnuts. There is, however, a major gap in agricultural insurance provision in the mainly small island economies of the Pacific region (FAO 2011) and also there are many challenges for other countries. For example, FAO (2011) points out the many roadblocks to well-functioning agricultural insurance markets in developing countries. These include the following.

- Government endorsement has remained essential to scaling up agricultural insurance in developing countries.

- People's understandings of insurance and its products are substantially lower among farmers in developing countries.

- The insurance market is challenged by the existence of a large number of small and marginal farmers in Asian countries.

- Index insurance is still being implemented on a pilot basis in many countries of Asia, and the market is dominated by indemnity-based crop insurance.

- Domestic insurers have less access to reinsurance markets and lack the capacity to deal with systemic risks.

Table 15 summarizes some of the key properties of agriculture insurance usage across Asia. 
Table 15: Overview of Agricultural Insurance Markets across Asia

\begin{tabular}{|c|c|c|c|c|c|c|c|}
\hline Country & $\begin{array}{l}\text { Income Grp } \\
\text { (2018) }\end{array}$ & $\begin{array}{l}\text { Crop } \\
\text { Insurance }\end{array}$ & $\begin{array}{l}\text { Voluntary/ } \\
\text { Credit Linked }\end{array}$ & Subsidy & Index Based & Major Crops & $\begin{array}{c}\text { First } \\
\text { Scheme }\end{array}$ \\
\hline Bangladesh & LMI & $\checkmark$ & Voluntary & $\checkmark$ & $x$ & Rice & 1977 \\
\hline Bhutan & LMI & $x$ & NA & $x$ & $x$ & NA & NA \\
\hline Cambodia & LMI & $x$ & NA & $\checkmark$ & $\checkmark$ (Pilot) & NA & 2019 \\
\hline China, People's Republic of & UMI & $\checkmark$ & Voluntary & $\checkmark$ & $\checkmark$ & Crops and livestock & 1982 \\
\hline India & LMI & $\checkmark$ & Credit linked & $\checkmark$ & $\checkmark$ & All major crops and livestock & 1985 \\
\hline Indonesia & LMI & $\checkmark$ & Voluntary & $\checkmark$ & $\checkmark$ (Pilot) & Rice & 2011 \\
\hline Lao People's Democratic Republic & LMI & $x$ & NA & $\checkmark$ & $\checkmark$ (Pilot) & NA & NA \\
\hline Malaysia & UMI & $x$ & NA & $x$ & $x$ & NA & NA \\
\hline Myanmar & LMI & $x$ & NA & $\checkmark$ & $\checkmark$ (Pilot) & NA & 2018 \\
\hline Nepal & $\mathrm{LI}$ & $\checkmark$ & Voluntary & $\checkmark$ & $x$ & NA & 2013 \\
\hline Pakistan & LMI & $\checkmark$ & Credit linked & $\checkmark$ & $x$ & Crops and livestock & 2008 \\
\hline Philippines & LMI & $\checkmark$ & Credit linked & $\checkmark$ & $\checkmark$ (Pilot) & $\begin{array}{l}\text { Rice; corn; high-value commercial } \\
\text { crops (HVCC); livestock; fishery }\end{array}$ & 1980 \\
\hline Sri Lanka & LMI & $\checkmark$ & Voluntary & $\checkmark$ & $\checkmark$ & Rice, vegetables & 1961 \\
\hline Thailand & UMI & $\checkmark$ & Voluntary & $\checkmark$ & $\checkmark$ (Pilot) & Rice, cotton, maize, sorghum & 1978 \\
\hline Viet Nam & LMI & $\checkmark$ & Voluntary & $\checkmark$ & $x$ & All crops and livestock & 1982 \\
\hline
\end{tabular}

$\mathrm{LMI}=$ lower-middle income, $\mathrm{NA}=$ not applicable, $\mathrm{UMI}=$ upper-middle income, $\mathrm{LI}=$ lower income.

Note: Where multiple schemes operate in a single market, we provide the best reflection of that single market.

Source: Authors' own based on data from Grantham Research Institute on Climate Change and the Environment. 2012-2018. Disaster Risk Transfer Scheme Database.

http://www.Ise.ac.uk/GranthamInstitute/evaluating-the-resilience-impact-of-climate-insurance-erici/ (accessed April 2019). 
This overview provides a snapshot of some of the key features of disaster and climate risk insurance schemes (and the markets they exist in). We have seen that there is still substantial room for market development and expansion across Asia. A mix of sovereign, meso, small and medium-sized enterprises, and microinsurance schemes operate currently to address a wide variety of risks (catastrophe, multiperil, and named peril). Finally, without subsidies and bundling and/or compulsion many markets are likely to collapse or, at the very least, would experience far lower penetration rates.

\section{INSURANCE AND RESILIENCE}

The previous section has described the current state of risk transfer schemes across Asia using the updated database. As their core function, all the schemes offer financial support to those who take out or receive the cover, either once they have experienced a loss or when a preset event is occurring, such as a lack of rainfall. Insurance can play a significant role in society's ability to recover from disasters through its risk transfer role by spreading and smoothing risks, providing faster and more efficient recovery, offering certainty about postdisaster support, helping to reduce immediate welfare losses and consumption reduction, and reducing the need for budgetary changes (see Hallegatte 2014, Clarke and Dercon 2009). If and how the schemes in the database fulfill this ambition is often less than clear; and insurers, governments, and the insured may have different views on this.

This section examines how the schemes in the database instruments can also influence risk reduction efforts, increase resilience, and support adaptation to climate change. Importantly, in times of changing climate, and rising exposure and vulnerability, it is essential to consider what role insurance schemes can play for climate risk management and adaptation efforts, at the very least to ensure that schemes can continue to be viable in the future. Many analysts have argued that insurance can play a role in ex ante risk reduction measures apart from its role in recovery and reconstruction (Schäfer, Warner, and Kreft 2018). However, such a notion has also been contested. In the context of the United Nations Framework Convention on Climate Change's Loss and Damage discourse, a recent study (Linnerooth-Bayer et al. 2019) argues that the preventive role of insurance through incentives is not well established and insurance might lead to disincentives through moral hazard. In an early investigation of the 2012 database, Surminski and Oramas-Dorta (2014) found very few schemes show any link between risk transfer and risk reduction in the case of flood insurance schemes, while the large majority appear not to formally or informally address risk reduction. Following the same methodology and looking at publicly available information, the analysis established three different degrees of linkages between risk transfer and risk reduction across schemes in Asia. These are

- no association: schemes where there is no documented link to any risk reduction measures;

- indirect association: where risk transfer is considered one element within an overall policy framework or strategy for disaster risk reduction or adaptation; and

- direct association: where a risk transfer scheme explicitly supports risk reduction efforts as part of its operation.

According to the 2012 database, just over one-third of schemes offered explicit support for risk reduction. In the current data, we see that this number has gone up to around two-thirds. This could be an indication of growing acceptance from those designing or operating the schemes of the need for more holistic measures-recognizing that insurance is no silver bullet in response to rising risk levels. 
However, the database is limited in its ability to inform if and how risk transfer is changing risk behavior and influencing future risk creation. This remains difficult to judge. Table 16 attempts to capture the landscape of risk reduction activities as they relate directly to insurance schemes for disaster and climate risks.

While this overview provides some high-level pointers, further details on the nature of the risk reduction elements and how they are used can only be gained through detailed case study analysis. Measuring the impact of insurance, including on resilience and risk levels, remains difficult and no accepted methodology exists. One example of a detailed impact assessment study is the index-based livestock insurance scheme in Mongolia. The scheme provided subsidized insurance to Mongolian herders, up to 2016. Bertram-Huemmer and Kraehnert (2015) recorded increased survival rates for the herder's livestock as a result of index-based livestock insurance during 2009-2010.

The Munich Climate Insurance Initiative has proposed a different methodology for assessing the resilience impact of insurance, based on the resilience concept of Bahadur et al. (2015), which describes resilience as the ability to do the following:

- Anticipate: estimate weather event impacts and the measures and costs required to address them.

- Absorb: cope with the impacts of shocks and absorb the effects of the event.

- Adapt: adjust to potential damage, take advantage of opportunities or respond to consequences.

- Transform: alter the fundamental attributes of a system to improve resilience to weather events. 
Table 16: Resilience and Disaster Risk Transfer Schemes

\begin{tabular}{|c|c|c|c|c|c|}
\hline Country & Income (2018) & $\begin{array}{c}\text { Risk Reduction/ } \\
\text { Preparedness } \\
\text { Activities }\end{array}$ & $\begin{array}{c}\text { Risk Awareness } \\
\text { Raising }\end{array}$ & $\begin{array}{l}\text { Risk Management } \\
\text { Capacity Building }\end{array}$ & $\begin{array}{c}\text { Physical Risk } \\
\text { Reduction }\end{array}$ \\
\hline Afghanistan & $\mathrm{LI}$ & $x$ & $x$ & $x$ & $x$ \\
\hline Bangladesh & LMI & $\checkmark$ & $x$ & $\checkmark$ & $x$ \\
\hline Bhutan & LMI & $x$ & $x$ & $x$ & $x$ \\
\hline Cambodia & LMI & $x$ & $x$ & $x$ & $x$ \\
\hline China, People's Republic of & UMI & $\checkmark$ & $x$ & $\checkmark$ & $\checkmark$ \\
\hline India & LMI & $\checkmark$ & $\checkmark$ & $\checkmark$ & $\checkmark$ \\
\hline Indonesia & LMI & $\checkmark$ & $x$ & $x$ & $x$ \\
\hline Lao People's Democratic Republic & LMI & $x$ & $x$ & $x$ & $x$ \\
\hline Malaysia & UMI & $x$ & $x$ & $\checkmark$ & $x$ \\
\hline Myanmar & LMI & $x$ & $x$ & $x$ & $x$ \\
\hline Nepal & $\mathrm{LI}$ & $\checkmark$ & $x$ & $\checkmark$ & $x$ \\
\hline Pacific nations & LI/LMI & $\checkmark$ & $x$ & $\checkmark$ & $x$ \\
\hline Pakistan & LMI & $\checkmark$ & $\checkmark$ & $x$ & $x$ \\
\hline Philippines & LMI & $\checkmark$ & $\checkmark$ & $\checkmark$ & $\checkmark$ \\
\hline Sri Lanka & LMI & $\checkmark$ & $x$ & $\checkmark$ & $x$ \\
\hline Thailand & UMI & $x$ & $x$ & $x$ & $x$ \\
\hline Viet Nam & LMI & $\checkmark$ & $x$ & $x$ & $x$ \\
\hline
\end{tabular}


However, evidence for the impact of climate insurance on these elements is relatively sparse. A recent review by InsuResilience identified positive changes in some indicators of resilience as a result of climate insurance (Table 17).

\title{
Table 17: Evidence from Munich Climate Insurance Initiative's InsuResilience Review
} on Climate Insurance for the Poor

\author{
Resilience element \\ Indicators that show improvement in this element as a result of access to climate insurance \\ Anticipate \\ Promote risk assessment \\ Absorb \\ Improve financial liquidity after disaster, reduce distress asset sales, increase food security, \\ enable rapid recovery \\ Adapt \\ Increase savings, increase investment in higher risk activities, increase productivity, improve \\ conditions to take up credits, promote risk reduction behavior \\ Transform \\ Meeting the aforementioned attributes is a precondition for transformation, for example, \\ establishing a culture of prevention \\ Source: Schaefer, Laura, and Eleanor Waters. 2016. Climate Risk Insurance for the Poor \& Vulnerable: How to Effectively Implement the Pro-poor \\ Focus of InsuResilience. Munich Climate Insurance Initiative: Bonn, Germany. http://www.climate-insurance.org/fileadmin/mcii/documents/ \\ MClI_2016_CRI_for_the_Poor_and_Vulnerable_full_study_lo-res.pdf.
}

To address this limitation in understanding how insurance can support the resilience and adaptation of its beneficaries, we are currently testing a new methodology with several insurance schemes, including agricultural insurance in India, as part of the Evaluating the Resilience Impacts of Climate Insurance Project. Using a set of survey questions, we are investigating subjective resilience among farmers in the disaster-prone Western Indian state of Maharashtra. Using an in-depth household-structured questionnaire, focus group discussions, and expert elicitation over a 2-year period, the study aims to measure and examine subjective resilience to disasters in the context of crop insurance. This work builds upon the expertise of existing resilience frameworks from FAO and Food Security Information Network groups (FAO 2014, 2015; Constas et al. 2014) and proposes the use of subjective resilience indicators to gain a better understanding of what role insurance can play for wellbeing in the face of shocks and stressors (Clare et al. 2017). Subjective indicators specifically consider how respondents view their own resilience and ask about their views on the impact that instruments such as insurance have on their life. This approach also investigates the complementarities and differences between the knowledge we gain through more commonly used objective, metrics such as calculating risk levels, compared to the knowledge gained through the use of subjective metrics. At the same time, this methodology can be used to create awareness and the understanding of resilience drivers among those involved in designing and implementing insurance schemes. The work in Maharashtra is based on close interactions across stakeholders, and initial findings from the survey are already being fed back to decision makers. 


\section{DISCUSSION AND CONCLUSION}

This paper provides a snapshot of the current use of insurance across emerging and developing countries in Asia. Our analysis shows that although the insurance sector is expanding, there are many countries that still have not started any kind of disaster or agricultural insurance schemes, such as Afghanistan, Bhutan, Cambodia, the Lao PDR, Malaysia, and Myanmar. In terms of the agricultural insurance market, the scenario has not changed much in the last decade. The agricultural insurance market is still largely dominated by the government-led subsidized crop insurance schemes. Further, many of the countries do not have any agricultural insurance schemes except pilot programs recently launched. Additionally, there appears to be lack of insurance for natural disasters such as landslides, volcanic eruptions, and earthquakes in many Asian countries. The database also reveals the importance of support mechanisms for insurance schemes.

One of the ambitions of the paper was to dig deeper into the question of market-based insurance and its link with resilience. At this point, the analysis is still limited, and the data and evidence about actual impact on the ground seem weak. One important consideration when comparing insurance schemes and considering resilience impacts are the aims and objectives of the different stakeholders involved. Under the overarching goals of reducing poverty and supporting sustainable development, there can be different nuances of what the specific objectives of insurance are. For example, the design and development of insurance schemes can be guided by different aims such as: ${ }^{4}$

- protecting the livelihoods of the poor through insurance solutions against income reduction and loss of assets due to climate and disaster risk;

- promoting insurance market development as an essential element of financial risk management within the private sector; and/or

- supporting reliant and fast relief through ex ante climate and disaster risk financing (faster disaster relief).

It is obvious that there can be trade-offs between these different success criteria. Importantly, the timing of expected impacts from support measures can also vary, for example, in the context of market development, solvency, and support for those most vulnerable. There are also some ethical questions that need to be considered; for example, there may be concerns about private insurance companies standing to gain by receiving aid money via public premium support (e.g., direct commercial gain and opportunities to open new businesses), requiring robust evidence, monitoring and evaluation (Vivid Economics, Surminski Consulting, and Callund Consulting 2016). It is therefore important to establish priorities and conduct transparent discussions among partners to clarify aim and objectives. This also needs to include an agreement on the necessary monitoring indicators for those designing and supporting insurance schemes prior to design and implementation of any support measures.

Add to this, the notion of using insurance to increase resilience. We note that terminologies appear to have shifted and that more schemes refer to "resilience" and risk reduction than in 2012. This is likely the result of the shifting international discourse, led by InsuResilience and donors publicly committing to risk reduction and adaptation. What this actually means for success criteria, design, and implementation remains less clear, but current work on methodologies and new surveys on resilience impact are expected to shed further light on this.

\footnotetext{
4 See also Surminski and Vivid Economics 2018.
} 
For those wishing to support insurance schemes, it would be important to consider if and how any support measures, such as premium subsidy or capacity building, can influence the role that insurance plays for resilience. One example would be investment in risk reduction as a way to keep insurance viable and affordable. This was investigated by Vivid Economics, Surminski Consulting, and Callund Consulting (2016) for the United Kingdom's Department for International Development and for KfW (Surminski and Vivid Economics 2018). The studies find that determining the right mix in line with local conditions, needs, and capacity is therefore an important consideration. This also relates to the sequencing of support measures, where several support measures with cobenefits beyond insurance, such as risk reduction, capacity building, and technical assistance may be chosen first, to pave the way for an eventual insurance purchase. Depending on the level of preparedness and capacity for risk transfer within a country, the intervention may start relatively broad, with measures to improve risk understanding and institutional development. These efforts can be beneficial far beyond risk transfer. Technical capacity building for risk financing is another step, after which the eventual design and implementation of a risk pool (or indeed other risk transfer or financing instruments) can follow, if deemed suitable and relevant for the country (Vivid Economics, Surminski Consulting, and Callund Consulting 2016).

On the flip side, there may be further unintended consequences that would not feature in any standard cost-effectiveness assessment. This can occur when support measures create the expectation that donor financing will take care of the problem, creating an overdependency. Another unforeseen consequence is, if support measures come with a range of instructions and conditions that lead governments to avoid ownership and buy-in, they may end up implementing projects, but not creating their own internal technical capacity to evaluate them nor critically reflect on whether or not the sovereign risk pool meets their needs and requirements. Furthermore, providing concessional insurance may have the perverse or unintended behavioral effect of inducing excessive risk-taking or less consideration of disaster risk when making development decisions. For example, infrastructure planning can generate a false sense of security and if this effect is strong, the cost effectiveness of an intervention may be sharply reduced. This could be averted by linking concessional insurance with risk mitigation measures, for example, through conditionality of cover. Some support measures are more prone to these distortions than others. Some may also negatively impact existing social safety net structures or crowd out other disaster risk management efforts. Using the database to assess the current application of insurance is a useful starting point for more in-depth assessment of the implementation and impacts of insurance. As highlighted above, much of this data is not available at a global level or in a standard format. Indeed, there is no common methodology for impact assessments and many schemes lack transparency about monitoring and evaluation. This is a key area that will require capacity building efforts and collaboration between donors-those who provide insurance schemes and other partners such as civil society-to ensure that the use of insurance can support climate adaptation and resilience, and to avoid costly maladaptation or unintended consequences. 


\section{DATA APPENDIX}

\section{A. Introduction}

This document seeks to give the reader an insight into how the database was put together. The Grantham Risk Transfer Scheme Database documents existing schemes in middle- and low-income countries that seek to transfer risks associated with weather, climate, or other natural hazards. ${ }^{5}$

\section{B. What Constitutes a "Scheme"?}

Each entry in the database is called a "scheme." A scheme is defined by

- the transfer of risk away from entities in low- or middle-income countries, and

- the use of one or more ex ante market-based risk transfer instruments.

The most common types of "entities" are:

- groups of individuals and/or households and/or smallholder farmers;

- $\quad$ public and private organizations (e.g., businesses, microfinance institutes, nongovernment organizations, public authorities); and

- governments (national, provincial and/or local)

The entity from whom risk is transferred is called the beneficiary. This is usually, but not always, party to the transaction of a risk transfer instrument

By "ex ante risk transfer instrument," we mean that the risk is transferred before the occurrence of an event that might trigger a payout, such as an earthquake or heavy rainfall. By "market-based risk transfer instrument," we mean that the risk transfer instrument was priced, and that the risk was transferred through free, mutually agreeable exchange. ${ }^{6}$

Each scheme might cover a large or small number of beneficiaries. For example, a scheme might detail the provision of a pilot program to provide indemnity-based insurance to 200 cattle herders in Mongolia. Another scheme might detail the provision or multiperil index-based insurance that is sold to tens of thousands of crop farmers across India.

A large number of schemes in the database are also uniquely identified because of some form of central management, branding, or natural grouping. For example, in India, the government runs the "Modified National Agricultural Insurance Scheme." This program heavily subsidizes index-based insurance for smallholder crop farmers. Here, this enters the database as a single scheme that transfers risk from "small crop farmers," using a "multiperil, index-based insurance instrument." Another example might be the PRC's earthquake insurance program, which sells index-based insurance to "residential property owners."

5 Grantham Research Institute on Climate Change and the Environment. 2012-2018. Grantham Disaster Risk Transfer Scheme Database. http://www.Ise.ac.uk/Granthamlnstitute/evaluating-the-resilience-impact-of-climate-insurance-erici/ (accessed April 2019).

6 We restrict our attention to "market-based" schemes to ensure consistency and comparability. Many "nonmarket" approaches to risk transfer also exist-such as informal lending networks, precautionary savings, and semiliquid buffer capital stocks. 


\section{Purpose and History of the Database}

The purpose of the database is to identify the features of each scheme and analyze these features both across time and space. The first edition of the database was published in 2012 under the name ClimateWise Compendium of Disaster Risk Transfer Initiatives in the Developing World. It is a "living document," and was revised in 2016 and 2018. Since its conception, the database has been heavily revised both in terms of its content and its structure.

Data sources consulted for the current version of the database are mainly secondary in nature, consisting of public sector and private sector reports and publications by international research organizations and partnerships.

Further information has been provided by primary sources including, ClimateWise insurers; dedicated scheme and/or insurer websites; risk transfer web portals; and websites of international organizations, development banks, national governments, research institutions, nongovernment organizations, microfinance institutions, agricultural banks, etc.

\section{Sample Bias and Limitations}

Despite the care taken, we would expect that our sample of schemes in the database to have certain bias. These were unavoidable given the scope of our project and the methods used to collect the data. We briefly list these here, as any research conclusions must first consider such bias:

(i) Our researchers looked only at information written in English.

(ii) We were collecting secondary sources primarily from web-based resources. As such, less developed countries in terms of their information and communication networks will be underrepresented.

(iii) The larger the scheme, the more likely it is that information pertaining to this scheme was available. All else equal, the likelihood that smaller schemes were overlooked is higher.

(iv) Some countries might have been overrepresented, such as India, which is large and has put much information on the Internet, in contrast to countries such as Myanmar.

(v) The database might have some public sector bias, as information on many of the privately operated insurance schemes might not have been available in the public domain as compared to government schemes. 


\section{REFERENCES}

Alhassan, Abdul Latif, and Vera Fiador. 2014. "Insurance-Growth Nexus in Ghana: An Autoregressive Distributed Lag Bounds Cointegration Approach.” Review of Development Finance 4 (2): 83-96. doi:doi.org/10.1016/j.rdf.2014.05.003.

Aon Benfield. 2016. Global Insurance Market Opportunities, Insurance Risk Study, $11^{\text {th }}$ edition. http://thoughtleadership.aonbenfield.com/Documents/20160911-ab-analytics-gimo.pdf.

Asian Development Bank (ADB). 2015. Strengthening City Disaster Risk Financing in Viet Nam. Manila. https://think-asia.org/handle/11540/5275.

2018. Philippine City Disaster Insurance Pool: Rationale and Design. Manila. https://www.adb.org/publications/philippine-city-disaster-insurance-pool.

Bahadur, Aditya V., Maggie Ibrahim, and Thomas Tanner. 2010. The Resilience Renaissance? Unpacking of Resilience for Tackling Climate Change and Disasters. Sussex: Institute of Development Studies. https://opendocs.ids.ac.uk/opendocs/bitstream/handle/123456789/2368/The\%20resilience\% 20renaissance.pdf? sequence=1\&isAllowed=y.

Bahadur, Aditya, Katie Peters, Emily Wilkinson, Florence Pichon, Kirsty Gray, and Thomas Tanner. 2015. "The 3As: Tracking Resilience across BRACED." BRACED Working Paper. London: Overseas Development Institute.

Beck, Thorsten, and lan Webb. 2003. "Economic, Demographic, and Institutional Determinants of Life Insurance Consumption across Countries.” World Bank Economic Review 17 (1): 51-87. doi:10.1093/wber/lhg011.

Béné, Christophe, Rachel Godfrey Wood, Andrew Newsham, and Mark Davies. 2012. "Resilience: New Utopia or New Tyranny? Reflection about the Potentials and Limits of the Concept of Resilience in Relation to Vulnerability Reduction Programmes." Institute of Development Studies Working Papers Volume 2012, Number 405, 1-61. Sussex: Institute of Development Studies. doi:10.1111/j.2040-0209.2012.00405.x.

Bertram-Huemmer, Veronika, and Kati Kraehnert. 2015. "Does Index Insurance Help Households Recover from Disaster? Evidence from IBLI Mongolia." Discussion Paper No. 1515. Berlin: German Institute for Economic Research, DIW. https://ideas.repec.org/p/diw/diwwpp/dp1515.html.

Breckner, Miriam, Florian Englmaier, Till Stowasser, and Uwe Sunde. 2016. "Resilience to Natural Disasters-Insurance Penetration, Institutions, and Disaster Types.” Economics Letters 148: 106-10.

Clare, Abbie, Rebecca Graber, Lindsey Jones, and Declan Conway. 2017. "Subjective Measures of Climate Resilience: What is the Added Value for Policy and Programming?" Global Environmental Change 46: 17-22.

Clarke, Daniel, and Stefan Dercon. 2009. "Insurance, Credit, and Safety Nets for the Poor in a World of Risk." United Nations Department of Economic and Social Affairs Working Paper No. 81. 
Clarke, Daniel, Olivier Mahul, Richard Poulter, Tse Ling Teh. 2016. “Evaluating Sovereign Disaster Risk Finance Strategies: A Framework.” World Bank Policy Research Working Paper No. 7721. Washington, DC: World Bank. http://documents.worldbank.org/curated/en/430111468184437717/ pdf/WPS7721.pdf.

ClimateWise. 2012. Compendium of Disaster Risk Transfer Initiatives in the Developing World. Cambridge: Cambridge Institute for Sustainability Leadership. https://www.cisl.cam.ac.uk/business -action/sustainable-finance/climatewise/pdfs/climatewise-compendium-of-disaster-risktransfer.xlsm/view.

Constas, Mark A., Timothy R. Frankenberger, John Hoddinott, Nancy Mock, Donato Romano, Chris Bene, and Dan Maxwell. 2014. "A Common Analytical Model for Resilience Measurement: Causal Framework and Methodological Options." Food Security Information Network Technical Series No. 2. Food Security Information Network published by Rome: Food and Agriculture Organization, Rome: World Food Programme, and Washington DC: International Food Policy Research Institute. https://www.fsnnetwork.org/common-analytical-model-resilience-measurement -causal-framework-and-methodological-options.

Dash, Saurav, Rudra P. Pradhan, Rana P. Maradana, Kunal Gaurav, Danish B. Zaki, and Manju Jayakumar. 2018. "Insurance Market Penetration and Economic Growth in Eurozone Countries: Time Series Evidence on Causality." Future Business Journal 4 (1): 50-67.

Di Falco, Salvatore, Felice Adinolfi, Martina Bozzola, and Fabian Capitanio. 2014. "Crop Insurance as a Strategy for Adapting to Climate Change." Journal of Agricultural Economics 65 (2): 485-504. doi:10.1111/1477-9552.12053.

Esho, Neil, Anatoly Kirievsky, Damian Ward, and Ralf Zurbruegg. 2004. "Law and the Determinants of Property-Casualty Insurance." Journal of Risk and Insurance 71 (2): 265-83. doi:10.1111/j.00224367.2004.00089.x.

Farrin, Kathleen, and Mario J. Miranda. 2015. "A Heterogeneous Agent Model of Credit-Linked Index Insurance and Farm Technology Adoption.” Journal of Development Economics 116: 199-211.

Food and Agriculture Organization of the United Nations (FAO). 2011. "Agricultural Insurance in the Asia Pacific Region, Food and Agriculture Organization of the United Nations Regional Office for Asia and the Pacific Bangkok, 2011.” Rome. http://www.fao.org/3/i2344e/i2344e00.pdf.

2014. "Resilience Index Measurement and Analysis Model." Rome.

_. 2015. “SHARP: A Participatory Tool to Assess Climate Resilience.” Rome.

2016. The Impact of Disasters on Agriculture and Food Security. Rome. http://www.fao.org/3/a -i5128e.pdf.

Ghesquiere, Francis, and Mahul Olivier. 2010. "Financial Protection of the State against Natural Disasters: A Primer." World Bank Policy Research Working Paper No. WPS 5429. Washington, DC: World Bank. http://documents.worldbank.org/curated/en/227011468175734792/ Financial-protection-of-the-state-against-natural-disasters-a-primer. 
Ghosh, Amlan. 2013. "Does Life Insurance Activity Promote Economic Development in India: An Empirical Analysis.” Journal of Asia Business Studies 7 (1): 31-43. doi:10.1108/15587891311301007.

Giné, Xavier, and Dean Yang. 2009. "Insurance, credit, and technology adoption: Field experimental evidence from Malawi.” Journal of Development Economics 89 (1): 1-11.

Global Facility for Disaster Reduction and Recovery. 2015. Pacific Catastrophe Risk Insurance Pilot: From Design to Implementation: Some Lessons Learned. Washington DC: International Bank for Reconstruction and Development, International Development Association or The World Bank. https://www.gfdrr.org/sites/default/files/publication/Pacific_Catastrophe_Risk_Insurance-Pilot _Report_140715(1).pdf.

Golnaraghi Maryam, Swenja Surminski, and Kai-Uwe Schanz. 2016. An Integrated Approach to Managing Extreme Events and Climate Risks: Towards a Concerted Public-Private Approach. Zurich: The Geneva Association. https://www.genevaassociation.org/sites/default/files/researchtopics-document-type/pdf_public/20160908_ecoben20_final.pdf. Grantham Research Institute on Climate Change and the Environment. 2012-2018. Disaster Risk Transfer Scheme Database. Grantham Research Institute on Climate Change and the Environment. http://www.Ise.ac.uk/Granthamlnstitute/evaluating-the-resilience-impact-of -climate-insurance-erici/ (accessed April 2019).

Hallegatte, Stephane. 2014. "Economic Resilience: Definition and Measurement." World Bank Policy Research Working Paper No. 6852. Washington, DC: World Bank. https://openknowledge .worldbank.org/ handle/10986/18341.

Hess, Ulrich, and Peter Hazell. 2016. Innovations and Emerging Trends in Agricultural Insurance. How Can We Transfer Natural Risks Out of Rural Livelihoods to Empower and Protect People? Eschborn, Germany: Deutsche Gesellschaft für Internationale Zusammenarbeit (GIZ) GmbH.

Hussels, Stephanie, Damian Ward, and Ralf Zurbruegg. 2005. "Stimulating the Demand for Insurance." Risk Management and Insurance Review 8 (2): 257-78.

InsuResilience. 2017. https://www.insuresilience.org/about/.

Intergovernmental Panel on Climate Change. 2012. "Managing the Risks of Extreme Events and Disasters to Advance Climate Change Adaptation." In A Special Report of Working Groups I and II of the Intergovernmental Panel on Climate Change, 555-564, 582, edited by C.B. Field, V. Barros, T.F. Stocker, D. Qin, D.J. Dokken, K.L. Ebi, M.D. Mastrandrea, K.J. Mach, G.-K. Plattner, S.K. Allen, M. Tignor, and P.M. Midgley. Cambridge, UK, and New York, USA: Cambridge University Press.

- 2014. "Summary for Policymakers." In Climate Change 2014: Impacts, Adaptation, and Vulnerability. Part A: Global and Sectoral Aspects. Contribution of Working Group II to the Fifth Assessment Report of the Intergovernmental Panel on Climate Change, 1-32, edited by C.B. Field, V.R. Barros, Dokken D, K.J. Mach, M.D. Mastrandrea, T.E. Bilir, M. Chatterjee, K.L. Ebi, Y.O. Estrada, R.C. Genova, B. Girma, E.S. Kissel, A.N. Levy, S. MacCracken, P.R. Mastrandrea, and L.L.White. Cambridge, UK, and New York, USA: Cambridge University Press. 
International Monetary Fund. 1980-2018. Data Mapper. https://www.imf.org/external/datamapper/ NGDPD@WEO/OEMDC/ADVEC/WEOWORLD.

Linnerooth-Bayer JoAnne, Swenja Surminski, Laurens M. Bouwer, Ilan Noy, and Reinhard Mechler. 2019. "Insurance as a Response to Loss and Damage?" In Loss and Damage from Climate Change. Climate Risk Management, Policy and Governance, edited by R. Mechler, L.M. Bouwer, T. Schinko, S. Surminski, and J. Linnerooth-Bayer. Cham, Switzerland: Springer.

Lloyds of London. 2018. A World at Risk: Closing the Insurance Gap. https://www.lloyds.com/news-and -risk-insight/risk-reports/library/understanding-risk/a-world-at-risk.

Mahul, Olivier, and Charles J. Stutley. 2010. Government Support to Agricultural Insurance: Challenges and Options for Developing Countries. Washington DC: The World Bank. https://openknowledge .worldbank.org/handle/10986/2432.

Mechler, Reinhard, Laurens M. Bouwer, JoAnne Linnerooth-Bayer, Stefan Hochrainer-Stigler, Jeroen C. J. H. Aerts, Swenja Surminski, and Keith Williges. 2014. "Managing Unnatural Disaster Risk from Climate Extremes." Nature Climate Change 4: 235-37. doi:10.1038/nclimate2137.

Meyer, Richard L., Peter B. Hazell, and Panos Varangis. 2017. Unlocking Smallholder Credit: Does CreditLinked Agricultural Insurance Work? Washington, DC: World Bank. http://documents.worldbank .org/curated/en/515371511848930976/Unlocking-Smallholder-Credit-Does-Credit-LinkedAgricultural-Insurance-Work.

Microinsurance Network. 2018. The World Map of Microinsurance Network. http://worldmapofmicro insurance.org/.

Narube, Savenaca. 2015a. Pacific Disaster Risk Financing and Insurance Program. Pacific Catastrophe Risk Insurance Pilot (PCRIP) Country Consultation Report. Secretariat of the Pacific Community: New Caledonia.

2015b. Pacific Catastrophe Risk Insurance Pilot (PCRIP): Establishment of a Management Entity, Secretariat of the Pacific Community.

O'Hare, Paul, lain White, and Angela Connelly. 2016. "Insurance as Maladaptation: Resilience and the 'Business as Usual' Paradox." Environment and Planning C-Government and Policy 34 (6): 117593. doi:10.1177/0263774x15602022.

Panda, Architesh, Upasna Sharma, K.N. Ninan, and Anthony Patt. 2013. "Adaptive Capacity Contributing to Improved Agricultural Productivity at the Household Level: Empirical Findings Highlighting the Importance of Crop Insurance." Global Environmental Change 23 (4): 782-90.

Ranger, Nicholas, and Swenja Surminski. 2013. "A Preliminary Assessment of the Impact of Climate Change on Non-life Insurance Demand in the BRICS Economies." International Journal of Disaster Risk Reduction 3: 14-30. https://doi.org/10.1016/j.ijdrr.2012.11.004.

Schaefer, Laura, and Eleanor Waters. 2016. Climate Risk Insurance for the Poor \& Vulnerable: How to Effectively Implement the Pro-poor Focus of Insuresilience. Bonn, Germany: Munich Climate Insurance Initiative. http://www.climate-insurance.org/fileadmin/mcii/documents/MCII_2016 _CRI_for_the_Poor_and_Vulnerable_full_study_lo-res.pdf. 
Schäfer, Laura, Koko Warner, and Sönke Kreft. 2018. "Exploring and Managing Adaptation Frontiers with Climate Risk Insurance." In Loss and Damage from Climate Change. Concepts, Methods and Policy Options, 317-341, edited by R. Mechler, L.M. Bouwer, T. Schinko, S. Surminski, J. Linnerooth-Bayer. Cham, Switzerland: Springer.

Schipper, Lisa, and Lara Langston. 2015. A Comparative Overview of Resilience Measurement Frameworks: Analysing Indicators and Approaches. London: Overseas Development Institute.

Surminski, Swenja. 2014. "The Role of Insurance in Reducing Direct Risk - The Case of Flood Insurance." International Review of Environmental and Resource Economics 7 (3-4): 241-78. http://doi:10.1561/101.00000062.

Surminski, Swenja, Laurens M. Bouwer, and JoAnne Linnerooth-Bayer. 2016. "How Insurance Can Support Climate Resilience." Nature Climate Change 6 (4): 332-33.

Surminski, Swenja, and Delioma Oramas-Dorta. 2014. "Flood Insurance Schemes and Climate Adaptation in Developing Countries." International Journal of Disaster Risk Reduction 7: 154-64. http://doi:10.1016/j.ijdrr.2013.10.005.

Surminski, Swenja, and Thomas Tanner, eds. 2016. Realising the 'Triple Dividend of Resilience' A New Business Case for Disaster Risk Management. Cham, Switzerland: Springer International Publishing.

Surminski, Swenja, and Vivid Economics. 2018. "Study on the Assessment of Tools to Support Climate and Disaster Risk Insurance." KfW Development Bank Materials on Development Finance No. 5. Frankfurt: KfW Development Bank.

Swiss Re. 2013. "Partnering for Food Security in the Emerging Markets." Sigma No. 1/2013. Zurich: Swiss Reinsurance Company.

Tanner, Thomas, Swenja Surminski, Emily Wilkinson, Robert Reid, Jun Rentschler, and Sumati Rajput. 2015. The Triple Dividend of Resilience: Realising Development Goals through the Multiple Benefits of Disaster Risk Management. London, UK: Overseas Development Institute and Washington, DC: International Bank for Reconstruction and Development/International Development Association or World Bank. https://www.gfdrr.org/sites/default/files/publication/The_Triple _Dividend_of_Resilience.pdf.

United Nations Economic and Social Commission for Asia and the Pacific. 2018. Opening Statement at Innovative Financing for Disaster Risk Reduction in Asia-Pacific, delivered at the Innovative Financing for Disaster Risk Reduction in Asia-Pacific, United Nations Headquarters, New York. https://www.unescap.org/speeches/opening-statement-innovative-financing-disaster-risk-reduction -asia-pacific.

Vivid Economics, Surminski Consulting, and Callund Consulting. 2016. "FINAL REPORT: Understanding the Role of Publicly Funded Premium Subsidies in Disaster Risk Insurance in Developing Countries." London: United Kingdom Department for International Development. https://www.gov.uk/dfid-research-outputs/final-report-understanding-the-role-of-publicly -funded-premium-subsidies-in-disaster-risk-insurance-in-developing-countries. 
Weingärtner, Lena, Catherine Simonet, and Alice Caravani. 2017. "Disaster risk insurance and the triple dividend of resilience.” Working paper 515. Overseas Development Institute: London.

World Bank. 1960-2018. GDP (Current US\$). World Bank Data. Washington, DC. https://data.worldbank .org/indicator/ny.gdp.mktp.cd?end=2018\&start=1960 (accessed April 2019).

—. 2015. "World Bank Group Offers Support to Aid Vanuatu's Recovery." Washington, DC: https://www.worldbank.org/en/news/press-release/2015/03/30/world-bank-group-offers-support -to-aid-vanuatu-recovery.

_2016a. Fiscal Disaster Risk Assessment and Risk Financing Options (English). Washington, DC.

_ 2016b. "Pacific Resilience Program" (P147839). Washington, DC.

—. 2016c. "Pacific Islands Prepare for a More Disaster Resilient Future." Washington, DC: https://www.worldbank.org/en/news/press-release/2015/06/19/pacific-islands-prepare-for-a -more-disaster-resilient-future. 


\section{Disaster Insurance in Developing Asia}

An Analysis of Market-Based Schemes

Well-designed insurance schemes can play an important role in increasing resilience to climate and disaster risks. This paper analyzes the status, types, and evolution of market-based disaster insurance schemes across developing Asia. The analysis shows that although the use of insurance is expanding, many countries still have no cover available. Where insurance coverage does exist, there is often a reliance on premium subsidies and means to compel uptake, such as mandatory coverage and credit-linked products. The paper discusses how this "carrot or stick" approach affects the sustainability and penetration of climate and disaster risk insurance schemes and efforts to increase resilience.

\section{About the Asian Development Bank}

ADB is committed to achieving a prosperous, inclusive, resilient, and sustainable Asia and the Pacific, while sustaining its efforts to eradicate extreme poverty. Established in 1966, it is owned by 68 members -49 from the region. Its main instruments for helping its developing member countries are policy dialogue, loans, equity investments, guarantees, grants, and technical assistance. 